\title{
Relation between Blood Level in Urine and Breakfast
}

\author{
Muhammad Imran Qadir, Aqsa khalid* \\ Institute of Molecular Biology and Biotechnology, Bahauddin Zakariya University, Multan, Pakistan \\ *Corresponding Authors: Aqsa khalid, Institute of Molecular Biology and Biotechnology, Bahauddin \\ Zakariya University, Multan, Pakistan
}

\begin{abstract}
The aspiration of this study was to seek for any relation between blood level in urine and a previous night. White blood cells or red blood cells, when seen in urine may indicate kidney disorder, liver or urinary tract infection. Urinalysis is a test which can detect blood in urine. 90 subjects from Bahauddin Zakariya University, Multan, Pakistan, were indulged in this study. It was resolved from the study that people who skip breakfast got negative results for test for detection of blood in urine. And maximum breakfast eaters as well got negative results from the same test.
\end{abstract}

Keywords: blood cells, breakfast, energy, calories, urinalysis

\section{INTRODUCTION}

The very first meal of the day is known as breakfast. The term is self-explanatory, that is breakfast is that course which breaks the fasting period of the previous night. There is variation observed in this morning meal according to the weather, tradition, customs, and taste. Every other state had their tables filled up with different kind of food which helps them in replenishing. With the passage of time, the tradition of having breakfast in the morning before going to schools, offices and work-places, is going to an end. People mostly rush to their work and skip the morning meal on daily basis, which causes very bad impact on their health. Later on, they crave for food before lunch time and as a result take "junk food" which harm them in any way.

Urinalysis is a test which can detect blood in urine. In most of the cases, cause of blood in urine is not that serious, but it is fatal sometimes. White blood cells or red blood cells, when seen in urine may indicate kidney disorder, liver or urinary tract infection. This urine test, urinalysis, must be carried out from time to time so as to keep an eye on liver, kidney or urinary tract infections. If left unchecked, it would cause serious health problems. Abdominal and back pain, pain while urinating are symptoms to worry about. Little amount of blood in urine is not dangerous, it may be due to medications, hectic workout or menstruation. But a larger amount of white blood cells or red blood cells indicate health problems like viral infection, urinary tract infection, blood disorder or inflammation in kidney.

The aspiration of this study was to see any relation between blood level in urine and the habit of skipping breakfast.

\section{MATERIAL AND MeTHOD}

90 subjects from Bahauddin Zakariya University, Multan, Pakistan, were indulged in this study.

\subsection{Measurement of Blood in Urine}

Urine samples were collected in clean and sterilized containers. At least an ounce of the sample was collected so as for verification analysis. Then the sample was delivered to the health care provider for detection of blood in urine. there were no such risks in the test.

\subsection{Statistical Analysis}

It was done with the help of MS Excel.

\section{RESULT AND DiSCUSSION}

As per analysis, out of 90 subjects, 20 subjects were male and the rest of them were female subjects that is 70 were females who marked the questionnaire. According to the questionnaire, 17 male and 
60 female subjects declared that they are amongst the breakfast eaters while 3 male and 10 female subjects had the bad habit of breakfast. Amongst the breakfast, 2 male and 12 female had positive results regarding blood in urine while 15 male and 48 female had negative results. As far as b are concerned, boating 3 male and 10 female had negative result while none of the breakfast skippers had positive results. (3-10) Relation between blood level in urine and breakfast is given in the table 1.G

Table1. Relation between blood level in urine and Breakfast

\begin{tabular}{|l|l|l|l|l|l|c|}
\hline \multicolumn{1}{|c|}{ Gender } & \multicolumn{1}{|c|}{ Breakfast likeliness } & Total & \multicolumn{2}{c|}{ Breakfast unlikeliness } & Total \\
\hline Urine test & $\begin{array}{l}\text { Blood in urine } \\
\text { (Plositive) }\end{array}$ & $\begin{array}{l}\text { Blood in urine } \\
\text { (Negative) }\end{array}$ & $\begin{array}{l}\text { Blood in urine } \\
\text { (Positive) }\end{array}$ & $\begin{array}{l}\text { Blood in urine } \\
\text { (Negative) }\end{array}$ & \\
\hline Male & $11.7 \%$ & $88.23 \%$ & 17 & $0 \%$ & $100 \%$ & 3 \\
\hline Female & $20 \%$ & $80 \%$ & 60 & $0 \%$ & $100 \%$ & 3 \\
\hline
\end{tabular}

\section{CONCLUSION}

It was resolved from the study that people who skip breakfast got negative results for test for detection of blood in urine. And maximum breakfast eaters as well got negative results from the same test.

\section{REFERENCES}

[1] Qadir MI, Malik SA (2010) Comparison of alterations in red blood cell count and alterations in hemoglobin concentration in patients suffering from rectal carcinoma undergoing 5 -fluorouracil and folic acid therapy. Pharmacologyonline, N1 3: 240-243.

[2] Qadir MI, Noor A (2018) Anemias. Rare \& Uncommon Diseases. Cambridge Scholars Publishing. Newcastle, England. ISBN: 978-1-5275-1807-0.

[3] Qadir MI, Javid A (2018) Awareness about Crohn's Disease in biotechnology students. GloAdv Res J Med Medical Sci, 7(3): 062-064.

[4] Qadir MI, Saleem A (2018) Awareness about ischemic heart disease in university biotechnology students. GloAdv Res J Med Medical Sci, 7(3): 059-061.

[5] Qadir MI, Ishfaq S (2018) Awareness about hypertension in biology students. Int J Mod Pharma Res, 7(2): 08-10.

[6] Qadir MI, Mehwish (2018) Awareness about psoriasis disease. Int J Mod Pharma Res, 7(2): 17-18.

[7] Qadir MI, Shahzad R (2018) Awareness about obesity in postgraduate students of biotechnology. Int J Mod Pharma Res, 7(2): 14-16.

[8] Qadir MI, Rizvi M (2018) Awareness about thalassemia in post graduate students. MOJ Lymphology \& Phlebology, 2(1): 14-16.

[9] Qadir MI, Ghalia BA (2018) Awareness survey about colorectal cancer in students of M. Phil Biotechnology at BahauddinZakariya University, Multan, Pakistan. Nov Appro in Can Study, 1(3): NACS.000514.2018.

[10] Qadir MI, Saba G (2018) Awareness about intestinal cancer in university student. Nov Appro in Can Study, 1(3): NACS.000515.2018.

Citation: Muhammad Imran Qadir, Aqsa khalid, "Relation between Blood Level in Urine and Breakfast", International Journal of Research Studies in Biosciences, 8(6), pp. 3-4. DOI: https:// doi.org/10.20431/23490365.0806002

Copyright: (C) 2020 Authors, This is an open-access article distributed under the terms of the Creative Commons Attribution License, which permits unrestricted use, distribution, and reproduction in any medium, provided the original author and source are credited. 